\title{
On the Role of Students' Subjectivity From the Perspective of Constructivism
}

\author{
Xiaoyan $\mathrm{Wu}$ \\ School of Humanities, Tianjin Agricultural University, Tianjin 300384, China \\ *Corresponding author. Email:wxysch@126.com
}

\begin{abstract}
Students are the main body in the teaching process and the "master" in the class. In the process of education and teaching reform, we should pay full attention to the subjective role of students. Based on the basic ideas of constructivism, this paper first expounds the basic content of students' subjectivity, then discusses the practical significance of attaching importance to the students' subjective role and finally puts forward some specific measures on how to improve the students' subjective role combined with the author's own teaching practice to realize the basic ideas advocated by Constructivism: taking students as the center, emphasizing students' active exploration and discovery of knowledge and the active construction of the meaning of knowledge.
\end{abstract}

Keywords: Constructivism, teaching, students, subjective role

\section{THE BASIC THOUGHT OF CONSTRUCTIVISM}

Constructivism is a theory about knowledge and learning, which emphasizes the initiative of learners. It holds that learning is a process of meaning generation and understanding construction based on the original knowledge and experience and this process is often completed in the social and cultural interaction. Constructivism is also an important branch of cognitive psychology, which is popular in the West in recent years. Constructivist learning theory originates from the cognitive development theory founded by Swiss psychologist Piaget. The content of the theory is very rich and the main viewpoints include: knowledge view, learning view, teaching view, teacher-student role view, teaching mode and so on. ${ }^{[1]}$ Among them, the discussion about teaching, the role of teachers and students and the teaching mode all emphasize an important core idea: taking students as the center, emphasizing students' active exploration and discovery of knowledge and the active construction of the meaning of knowledge. Based on the idea of Constructivism, this paper discusses the importance of students' subjectivity in the teaching process.

\section{THE MAIN CONTENT OF ROLE OF STUDENTS' SUBJECTIVITY}

The subject refers to the person who is engaged in practical and cognitive activities. Subjectivity refers to the fundamental common attribute of human beings as the subject of activities. It mainly contains the indispensable autonomy, initiative and creativity of human beings in conscious activities. No matter as the subject of practice, cognition or evaluation, human beings have the abovementioned fundamental commonalities. The basic framework of education and teaching is teachers and students and students are the main body in the teaching process.

\subsection{Students are the Main Body to Establish a Good Learning Atmosphere}

According to the principle of dialectical relationship between internal and external causes, external cause is the condition of change and internal cause is the basis of change. External cause acts through internal cause and promotes or hinders internal cause. In both students and learning atmosphere, students are the internal cause, while learning atmosphere is the external cause. And the quality of learning atmosphere will affect students' learning situation. Therefore, teachers should use various methods in the teaching process to stimulate students' interest in learning, correct students' learning attitude and make them realize that they are the builders of a good learning atmosphere. ${ }^{[2]}$ In the author's teaching process, to implement the student-centered education concept and use the "Online + offline" combination of teaching methods to stimulate students' interest in learning.

\subsection{Students are the Main Body of Teaching Quality Evaluation}

Teaching quality is reflected by teachers' teaching and students' learning but it must be determined by students' learning quality. Therefore, the evaluation and testing of 
teaching quality should be completed by testing students' learning quality. For example, how much knowledge and ability students have acquired and whether these knowledge and ability can be used in practical work etc. The current method of testing students' learning quality is no more than various types of examinations, but because the examination results can not accurately reflect the real level of students, so this method of evaluating students' learning quality can not be used as the real standard of evaluating teachers' teaching quality. ${ }^{[3]}$ We should evaluate and test the teaching quality of teachers through the investigation of the process of teachers' teaching activities, because in the teaching process, students are the direct objects of teaching activities, they can observe teachers' words and deeds, they have the most comprehensive contact and the deepest understanding of teachers and they are fully qualified and capable of having accurate and objective evaluation of teachers' teaching behavior. Therefore, teachers should pay attention to this method to give full play to students' subjectivity in evaluating teaching quality. In my own teaching process, I often communicate with students, listen to their opinions on teaching, change my teaching methods and fully respect the subjective role of students in teaching.

\subsection{Students are the Main Body of Teaching Interaction}

Teaching activity is a joint activity between teachers and students. It is a bilateral activity. Teachers are the main body of teaching activities and students should also be the main body of teaching activities. ${ }^{[4]}$ However, under the traditional teaching methods, students are only passive receivers in the classroom, completely ignoring the objective fact that students are the real subject in the teaching process, ignoring the subjective initiative of students in the classroom, so that students develop a kind of dependent thinking, lack of independence and creativity, which is difficult to adapt to the development of society. Therefore, we must recognize and respect the dominant position of students in the teaching interaction, which is fundamentally determined by the law of education, because the purpose of education is to enable students to achieve the requirements of educational goals and become useful talents to the society and the country. And the only way to achieve this goal is the quality of teaching, is the students' learning and performance, so it is groundless to ignore the dominant position of students in the teaching process.

\section{THE PRACTICAL SIGNIFICANCE OF ATTACHING IMPORTANCE TO STUDENTS' SUBJECTIVITY ROLE}

\subsection{The Improvement of Teaching Quality Needs to Pay Attention to the Subjective Role of Students}

It has been discussed that students are the main body of teachers' teaching quality evaluation, so we should pay attention to the subjective role of students. However, at present, in colleges and universities, there is a widespread lack of communication between teachers and students, teachers' teaching can not really meet the needs of students' learning. Attaching importance to students' subjectivity will help teachers to adjust and update their own educational contents, improve teaching methods, use new educational mean and improve teaching quality. Especially for some courses closely combined with reality, we should pay more attention to listening to students' opinions and understanding their needs for teaching. At the same time, we should attach importance to the subjective role of students, so that teachers and students are in an equal position. It can also stimulate students' learning enthusiasm, improve learning efficiency, and enable students to cultivate their own comprehensive quality, which in turn improves the quality of teachers' teaching.

\subsection{The Improvement of Students' Ability Needs to Pay Attention to the Subjective Role of Students}

With the development of economy, the society has higher and higher requirements for the quality of talents and the development of science and technology also requires to cultivating the comprehensive quality of talents. Therefore, students should cultivate their abilities in all aspects, such as self-learning ability, self-evaluation ability, self-control ability and so on. The cultivation of all these abilities depends on the school authorities and teachers' respect for students' subjective role in the teaching process. Because only in this way can students find their future position in the society, adapt to the requirements of the society well and make a reasonable allocation of human resources. Certainly, these abilities are not achieved in a day. They need the cooperation and coordination of school authorities, teachers and students.

\subsection{The Reform of Education and Teaching Needs to Pay Attention to the Subjective Role of Students}

It is an urgent requirement for the sustainable development of China's higher education in the new century to attach importance to the subjective role of students and improve 
the teaching quality in an all-round way. It is an inevitable choice to implement China's education policy and the idea of running a school based on quality. It is also an inevitable requirement to expand the scale of running a school and to survive and develop in the fierce competition. In order to carry out the reform of education and teaching in Colleges and universities in China, we must respect the subjectivity of students in the process of teaching and the improvement of education quality, treat students as the "masters" in the classroom and return their due rights and status. Only in this way can our education and teaching reform achieve good results.

\section{HOW TO IMPROVE STUDENTS' SUBJECTIVITY}

Constructivism holds that knowledge is not imparted by teachers but acquired by ways of meaning construction with the help of other people (including teachers and learning partners) in a certain social and cultural context. This means that students are the main body of learning and the subjectivity of students is not given to them by teachers, but is inherent to students as learners. Teachers should guide students correctly. The front mainly expounds the necessity of paying attention to the role of students' subjectivity. But in the actual reform process, how to improve the role of students' subjectivity is also a problem worthy of attention. In this part, the author will put forward specific measures to enhance the role of students' subjectivity combined with my own teaching practice based on the idea of constructivism.

\subsection{Establish a More Perfect Self-evaluation System of Students and Give Full Play to the Subjectivity of Students}

Students' self-evaluation system is to make students personally participate in the evaluation, make students clear that learning is their responsibility and their biggest task. Therefore, the school authorities, especially the head teacher, should guide the students correctly, so that students can form objective and fair evaluation for themselves, so as to cultivate students' ability of selfevaluation and adapt to the requirements of society well. ${ }^{[5]}$

\subsection{Change Our Concepts, Carry out the Modern Education Idea of Taking Students as the Centre and Cultivate the Harmonious Relationship between Teachers and Students}

In the traditional teaching, the teacher mainly plays the role of "speaker" and under this kind of indoctrination education system, students' subjective initiative can not be showed out. In addition, for a long time, teachers often appear in front of students with an authoritative image, which invisibly puts students in a passive and negative position, lacks the consciousness of active thinking and active participation, resulting in a larger psychological distance between teachers and students, which will undoubtedly increase students' psychological pressure and make the classroom atmosphere too serious. Therefore, teachers should change the traditional authoritative image and paternalistic style, respect students, create an equal and harmonious interpersonal environment, change the traditional idea of "teaching" as the focus but establish "learning" as the focus [6]. Just as the old saying goes, "give a man a fish, and you have fed him for today; tech a man to fish, and you have fed him for a lifetime." Teachers should be the guide and motivator of students' learning, walk out of the role of speakers, and establish the dominant position of students, so as to fully mobilize the enthusiasm of students' learning.

\subsection{Reform Teaching Methods, Cultivate Students Who Can Study Independently, and Really Improve Students' Ability}

The reform of teaching methods is a serious topic, because the current teaching methods are basically lecturing and this method has its advantages, that is, it can enable students to learn more systematic knowledge. However, from the perspective of cultivating students' abilities in all aspects, this method has great constraints, which is not conducive to students' autonomous learning. Combined with teaching practice, the author thinks that in the teaching process, while teaching the course, we should add some interaction and discussion links. Students can inspire and promote each other in the interaction and discussion, and the role of teachers is to put forward problems, solve disputes and make comprehensive comments. In this way, students not only produce new ideas and put forward new views in the process of learning, but also cultivate students' ability to acquire knowledge by themselves. At the same time, teachers improve teaching methods. In my opinion, there are mainly two methods as follows:

First is the teaching method of question setting. Every course has a certain theory. If the teacher just uses the abstract method to explain the theory step by step, the students will be in a passive position in the classroom, and the classroom will become very boring. Therefore, before explaining the theory, teachers can set questions to attract students' attention. For example, when teaching the content of "the factors affecting demand", the author first asked the students, "What kinds of factors do you mainly think about when you buy goods? What factors do you think will affect your buying behavior? " After putting forward the question, let the students discuss and answer first, and finally explain the question one by one on the basis of summarizing the students' answers. In this way, it is easier to give full play to students' initiative, and students can master what they are studying.

Second is the teaching method of research and discussion. The teaching method of research and discussion is mainly 
to guide students to conduct in-depth research on related teaching contents, so that students can use basic principles and research methods to understand and solve practical problems, mainly focusing on cultivating students' ability of independent thinking, and improving students' ability of analyzing and solving problems. The author pays attention to the use of this method in the actual teaching process. For example, when explaining the practical application of the tools of financial policy and monetary policy in Western Economics (macro), the author divides the students into several groups and let each group of students think about a series of macroeconomic policies adopted by China in recent years and form an article. Then students of each group make a speech about their article in class one by one and other groups can put forward their different views. Through such research and discussion teaching, students' thinking and vision of analyzing problems are expanded, and students' initiative is also improved.

\section{CONCLUSION}

Constructivism advocates learner-centered learning under the guidance of teachers. That is to say, it emphasizes the cognitive role of learners and does not ignore the guiding role of teachers. Teachers are helpers and promoters of meaning construction, rather than imparters and indoctrinators of knowledge. Students are the main body and the active constructors of information processing, rather than the passive recipients of external stimuli and the objects to be instilled. As the German educator Aristotle said: "the art of teaching is not to impart skills, but to encourage, awaken, and inspire students to learn to work with their hands, tongue and brain." Therefore, educators should really change the traditional teaching methods, because the indoctrination education of knowledge and skills will make people lose the ability of speculation and criticism. We should pay attention to the subjective role of students in the classroom, make students' learning become a conscious, active and independent behavior, and make them become the main body of learning activities.

\section{REFERENCES}

[1] Fan shide. "On the teaching methods of western economics in Chinese Universities," Journal of Nanjing Institute of audit, 2012(3):100-104. (In Chinese)

[2] Liang bin. "On the necessity of students' evaluation of teachers' teaching quality," Journal of Yunnan Police Officer Academy, 2004(2):14. (In Chinese)

[3] Xia jiangyi. "Research on the teaching of western economics based on Constructivism," Guizhou Normal University, 2009. (In Chinese)

[4] Wang fa. "The interaction of two subjects determines the quality of teaching," Journal of Pharmaceutical Education, 2004(2):6. (In Chinese)

[5] Wang yan. "Innovating teaching management in Colleges and Universities Promote the development of students' learning subjectivity," Journal of Higher Education, 2017(22):66-68. (In Chinese)

[6] Xu jing. "On the construction of school teaching management and the development of students," Journal of Training in China, 2016(20):95. (In Chinese) 